\title{
Prevalence of ectoparasites of carp fingerlings at Santaher, Bogra
}

\author{
M. D. Hossain ${ }^{1}$, M. Kabil Hossain ${ }^{2}$, M. Habibur Rahman ${ }^{3}$, A. Akter ${ }^{2}$ and D. A. Khanom ${ }^{1}$ \\ ${ }^{1}$ Department of Fisheries, Rajshahi University, ${ }^{2}$ Institute of Biological Sciences, Rajshahi University, ${ }^{3}$ Department of Zoology, \\ Rajshahi University, ${ }^{4}$ Department of Botany, Rajshahi University, Rajshahi, Bangladesh.
}

\begin{abstract}
The research work was conducted to find out the seasonal prevalence of ectoparasites of carp fingerlings. Seven species of parasites viz. Trichodina domerguei, Trichodina reticulata, Chilodonella cyprini, Myxobolus koi, Dactylogyroides tripathi, Dactylogyrus extensus and Dactylogyrus catlarius were recovered from 640 fingerlings of Silver carp (Hypophthalmicthys molitrix), Bighead carp (Ctenopharyngodon idella), Common carp (Cyprinus carpio), Thai punti (Puntius gonionotus), Catla (Catla catla), Rui (Labeo rohita) and Mrigal (Cirrhina mrigala) from different nursery ponds of Bogra district during June 2005 to May 2006. The highest prevalence (95\%) was in Trichodina domerguei and lowest (10\%) in Dactylogyrus catlarius during winter season. Average prevalence of protozoan and monogenean parasite was 37.16 in rainy season, 40.08 in winter season and 30.25 in summer season. Winter is the most disease occurring season of the year.
\end{abstract}

Key words: Ectoparasite, infestation, prevalence, fingerling, nursery pond

\section{Introduction}

The most important prerequisite of fish production is the availability of healthy fish fingerlings. One of the reasons often quoted, as constraint for aquaculture development in Bangladesh is the shortage of fish seed and one of the ways to meet this demand is to maximize production of fingerlings from available nursery and rearing ponds. High stocking density is being maintained during carp nursery operations, and this density induces bio-ecological stress to fry (Passino, 1984) nd make the fry more susceptible to the parasitic infection (Sneisko, 1974). It is evident from the available literature that parasitic diseases caused significant damage in nursery systems of carp, catfish and shellfish of Srilanka (Subashinghe, 1992), Malaysia (Leong, 1992), Indonesia (Angka, et al., 1982), Taiwan (Song et al., 1980) and India (Gopalkrishnan, 1961). The parasite community of fish shows considerable variation with the environmental conditions in which fish live.

It was observed that the prevalence of the disease was more in the winter season (Ahmed et al., 1991) and that again occurs in the same season every year. The present study was designed to investigate the prevalence, host specificity, infestation of ectoparasite in carp fingerlings of Bogra districts, Bangladesh.

\section{Materials and Methods}

The carp fingerlings of Hypophthalmicthys molitrix, Ctenopharyngodon idella, Cyprinus carpio, Catla catla, Labeo rohita, Cirrhinus mrigala and Puntius gonionotus were used as host fishes for the collection of ectoparasites and their identification. The study was conducted from June 2005 to May 2006 in Bogra district and a total of 640 carp fingerlings was observed for ectoparasites. In order to observe seasonal changes, the infected fishes were collected seasonally and immersed in $5 \%$ neutral formalin for preservation. The parasites were fixed according to the method suggested by Cable (1958). Monogenean parasites were identified following
Yamaguti (1963). For identification of protozoan parasites Lom (1960), Lucky (1971) and Kabata(1985) were followed. The prevalence was calculated as number of infested fish divided by number of observed fish multiplied by hundred. The water quality parameters viz., water temperature, alkalinity, ammonia, free $\mathrm{CO}_{2}$, dissolved oxygen, $P^{H}$ and total hardness were measured seasonally with the help of kit box. All recorded data were analyzed to calculate the prevalence of ectoparasites. The effect of locality and seasons were analyzed in terms of the percentage of parasites present.

\section{Results and Discussion}

The percentage of infection of fishes by protozoan parasites such as Trichodina domerguei, Trichodina reticulata, Chilodonella cyprini, Myxobolus koi and monogenean parasites such as Dactylogyrus catlarius, Dactylogyrus extensus, Dactylogyroides tripathi were 62, 50, 30, 22, 40, 35, 25 in rainy season, 95, 67, 40, 52, 10, 25, 15 in winter and 85, 20, 24, 37, 25, 18, 14 in summer respectively (Table 1). The seasonal prevalence of protozoan and monogenean parasites were 41.00 and 33.33, 63.50 and 16.67, 41.50 and 19.00 during rainy season, winter season and summer season respectively. The average prevalence of protozoan and monogenean parasite was 37.16 in rainy season, 40.08 in winter season and 30.25 in summer season (Table 2). The seasonal data revealed that the out break of diseases found in the winter season for particular species leads to a conclusion that a biological factor of the host as well as the water quality may play an important role in that period. The parasitic infestation fluctuated seasonally in all observed fishes (Table 1). Usually the parasites cause diseases to fishes and as the fingerlings are delicate, they are more susceptible to diseases. So they die very quickly. As the water quality parameters fluctuate very quickly during winter and summer season, fish becomes affected 
with diseases in these two seasons. The water temperature, alkalinity, ammonia, free $\mathrm{CO}_{2}, \mathrm{DO}, \mathrm{P}^{\mathrm{H}}$ \& total hardness measured were $30.57^{\circ} \mathrm{C}, 137.50 \mathrm{ppm}$, 2.75ppm, 10.97ppm, 5.80ppm, 6.52 and $142.50 \mathrm{ppm}$ in rainy season, $21.12^{\circ} \mathrm{C}, 126.25 \mathrm{ppm}, 1.37 \mathrm{ppm}, 8.62 \mathrm{ppm}$, 8.67ppm, 7.0, and $113.75 \mathrm{ppm}$ in winter season and
27.75ํㄷㄴ. 108.75ppm, 1.6ppm, 9.77ppm, 7.02ppm, 8.15ppm and $121.25 \mathrm{ppm}$ in summer season respectively. Their Mean and $\pm S D$ value were 25.48 \pm 3.892 , $124.17 \pm 11.819$, 1.91 \pm 0.603 , 9.78 \pm 0.959 , $7.16 \pm 1.176, \quad 7.22 \pm 0.684$ and $125.83 \pm 12.176 p p m$ respectively (Table 3 ).

Table 1. Prevalence of individual ectoparasites in carp fingerlings in different seasons of the year.

\begin{tabular}{l|c|c|c|c}
\hline \multicolumn{1}{c|}{ Parasites } & Rainy season (\%) & Winter season (\%) & Summer season (\%) & Mean \\
\hline Trichodina domerguei & 62 & 95 & 85 & 80.67 \\
\hline Trichodina reticulata & 50 & 67 & 20 & 45.67 \\
\hline Chilodonella cyprini & 30 & 40 & 24 & 31.33 \\
\hline Myxobolus koi & 22 & 52 & 37 & 37.0 \\
\hline Dactylogyrus catlarius & 40 & 10 & 25 & 25.0 \\
\hline Dactylogyrus extensus & 35 & 25 & 18 & 26.0 \\
\hline Dactylogyroides tripathi & 25 & 15 & 14 & 18.0 \\
\hline
\end{tabular}

Note: Rainy season= June-September, winter season= October-January, summer season= February-May

Table 2. Seasonal prevalence of ectoparasites in carp fingerlings.

\begin{tabular}{c|c|c|c}
\hline Parasites & Rainy season (\%) & Winter season (\%) & Summer season (\%) \\
\hline Protozoan parasite & 41.00 & 63.50 & 41.50 \\
\hline Monogenean parasite & 33.33 & 16.67 & 19.00 \\
\hline Average & 37.16 & 40.08 & 30.25 \\
\hline
\end{tabular}

Table 3. Seasonal fluctuations of water quality parameters in nursery pond.

\begin{tabular}{c|c|c|c|c|c|c|c}
\hline Season & $\begin{array}{c}\text { Water temp. } \\
\left({ }^{\circ} \mathbf{C}\right)\end{array}$ & $\begin{array}{c}\text { Alkalinity } \\
(\mathbf{p p m})\end{array}$ & $\begin{array}{c}\text { Ammonia } \\
\mathbf{( p p m )}\end{array}$ & $\begin{array}{c}\text { Free CO } \\
\mathbf{( p p m )}\end{array}$ & $\begin{array}{c}\text { DO } \\
(\mathbf{p p m})\end{array}$ & $\boldsymbol{P}^{\boldsymbol{H}}$ & $\begin{array}{c}\text { Total hardness } \\
\mathbf{( p p m )}\end{array}$ \\
\hline Rainy & 30.57 & 137.5 & 2.75 & 10.97 & 5.8 & 6.52 & 142.5 \\
\hline Winter & 21.12 & 126.25 & 1.37 & 8.62 & 8.67 & 7.0 & 113.75 \\
\hline Summer & 24.75 & 108.75 & 1.6 & 9.77 & 7.02 & 8.15 & 121.25 \\
\hline Mean & 25.48 & 124.17 & 1.91 & 9.78 & 7.16 & 7.22 & 125.83 \\
\pm SD & \pm 3.592 & \pm 11.819 & \pm 0.603 & \pm 0.959 & \pm 1.176 & \pm 0.684 & \pm 12.176 \\
\hline
\end{tabular}

Fish fingerlings become more susceptible to pathogen because of their immature immune system (Anderson, 1974), which support the present findings. Kabata (1985) reported that shallow ponds and stagnant water favours the multiplicity of ciliate like Trichodina. In Philippines Lumanlan et al. (1992) reported Trichodina as the most prevalent ectoparasite followed by Dactylogyrus. The prevalence of Trichodina domerguei and Dactylogyrus catlarias were found highest. These findings of the present study agreed with the findings of Subasinghe (1992). Sharif and Vijarungam (1986) reported these two parasites were the most common and caused mass mortality of fish during their study in the carp fish nursery operation system in Malaysia.
The fingerlings required more $\mathrm{O}_{2}$. During winter the water volume of fish habitat become reduced and water quality parameters deteriorates during this period (Table 3). So fingerlings become suffocated due to lake of $\mathrm{O}_{2}$ in water. Often the density of fingerlings remains higher in nursery pond. As a result water become polluted. So variety of diseases appear in nursery pond caused by ectoparasites. The value of water quality should be maintained properly to avoid the appearance of parasites in nursery pond.

\section{Acknowledgement}

The authors would like to express their gratitude and sincere thanks to the Chairman, Department of Fisheries, University of Rajshahi for giving permission and providing the laboratory facilities to fulfill the research work. 


\section{References}

Ahmed, A., Ali, S. M.K.\& Samad, A. 1991. Probable cause of fish ulcer in Bangladesh. Nutrition news. 14(1): 3p.

Anderson, D. P., 1974. Fish immunology. In: Diseases of fishes Stanisias. F. Sneiszko. F. \& Axelrod (eds.) H. R. F. H. publication Inc. New Jersey 07753 USA.

Angka, S.L, Promono S.U., Pasaribu F.H. \& Alifuddin M.1982. Isolasidan identificasi sasad renik peneyb abepidemi Peniyakid bersak mera pada ikan dilara Berat. Bull. Perikanan. 1: 1-14.

Cable, R.M.1958. An illustrated laboratory manual of Parasotology. Burgess Publishing Company, Minneapolis 15. Minn. 165.

Gopalkrisnan, V.1961. Observation on a new epidemical eye disease affecting the Indian Carp Catla catla (Hamilton-Buchanan). Indian J.Fish. 8: 222-232.

Kabata. Z. 1985. Parasites and diseases of Fish Cultured in the Tropics. Taylor and Francis, London and Philadelphia.

Leong, T.S. 1992. Diseases of brackish water and marine fish cultured in some Asian countries. In: Diseases in Asian Aquaculture 1 Shariff M., Subashinghe R.P. \& Arthur T.R. (.eds). Asian Fisheries Society, Philippines.

Lom. J. 1960."Trichodina reticulata Hirschmann and Partsch 1955 from Crucian carp, and T. domerguei f. latispina Dogel 1940 from Diaptomus " Protozoological Laboratory of the Czechoslovak academy of Science, Prague. Acta Societatis Zologicke. Bohemoslovenicae Svazek xxivCislo 3-1960-Str. 246-257.

Lucky, Z.1971. Methods for the diagnosis of fish diseases. Amerind Publishing Co. Pvt. Ltd. New Delhi, New York.
Lumanlan, S.C., Albaladejo. J.D., Bondad-Reartaso. M.G. \& Arthur, J.R., 1992. Fresh-water fishes imported into the Philippines: In: Diseases in Asian Aquaculture 1, (eds.). Shariff, M. Subashinghe R. P. and Arthur, J.R. Asian Fisheries Society, Philippines

Passino, D.R.M. 1984. Biochemical indicator in fish. An overview in contaminants effects in Fisheries, Cairns.V.W, Hodson. V.P. \& Nriagu J.O. (eds.). John Willy and Sons, USA.

Sharif, M. \& Vijiarungam, A F, 1986. The occurrence of parasites at the fish breeding station in peninsular Malaysia and their control. Proc. Intercont. Dev. Managem. Trop. Living Aquat. Resources, Serdang, Malaysia. 2-5 August 1983. pp 68-73.

Sneisko, S.F. 1974. The effect of environmental stress on out break of infectious diseases of fishes, J. Fish. Biol. 6: 197-208.

Song, Y.L., Chen S.W., Kou G.H., Lin C.L. \& Ying Y.Y. 1980. Evaluation of Hivax vibrio, Angullarum baclevia in the vaccination of Milkfish (Chanos chanos) fingerlings. Fish. Dis. Res. III: 101-108.

Subashinghe, R.P. 1992. Hatchery disease of fresh water fishes in Srilanka. In: Diseases in Asian Aquculture I, Sharif M.,. Subashinghe R. P \& Arthur J.R. (eds.).Asian Fisheries Society, Philippines.

Yamaguti, S. 1963. Systema Helminthum vol. Acanthocephala of vertebrates. Interscience Publishers. New York.

Manuscript received on 28.05.2008, accepted on 23.09.2008 